\title{
Students' Competency as Candidates of Guidance and Counseling Counselors in the Implementation of Group Guidance Services
}

\author{
Suci Rahmawati ${ }^{1}$, Dasril $^{2 凶}$, Irman $^{3}$, Rina Yulitri ${ }^{4}$ \\ Bimbingan dan Konseling, Institut Agama Islam Negeri Batusangkar, Indonesia ${ }^{1,2,3,4}$, \\ email: indricantikaputri369@gmail.com¹, dasril@iainbatusangkar.ac.id ${ }^{2}$, \\ irman@iainbatusangkar.ac.id ${ }^{3}$, rinayulitri@iainbatusangkar.ac.id ${ }^{4}$ \\ DOI: $10.31958 /$ jies.v1i2.3160
}

\begin{tabular}{ll}
\hline Article info & \multicolumn{1}{c}{ Abstract } \\
\hline & This study aims to determine the competence of BK (Guidance and Counseling) \\
Article History & students as prospective counselors in implementing group guidance services \\
Recieved: & (BKp). This study used a descriptive quantitative method. The sample was \\
$22 / 03 / 2021$ & determined by using a purposive sampling technique. Likert scale model was \\
Accepted: & chosen as the instrument of this research. The research subjects were BK students \\
$17 / 11 / 2021$ & of IAIN Batusangkar in the 2019/2020 academic year. The results revealed that the \\
Published: & students competency in implementing group guidance services are divided into \\
$30 / 11 / 2021$ & four categories, they are the competence at transitional stage which is the lowest \\
& (63\%), competence at activity stage which is in high category (83\%), competence \\
Corresponding author & $\begin{array}{l}\text { at conclusion is categorized low (73\%), and last competence at the final stage } \\
\text { which is moderate (77\%). The research findings have an impact on producing }\end{array}$ \\
& reliable prospective counselors in the future by having the competence to provide \\
& group guidance services..
\end{tabular}

Keywords: Students' Guidance and Counseling, Group Guidance Services

\begin{abstract}
Abstrak
Penelitian ini bertujuan untuk mengetahui bagaimana kompetensi mahasiswa Bimbingan dan Konseling sebagai calon konselor dalam pelaksanaan layanan bimbingan kelompok (BKp). Penelitian ini menggunakan metode kuantitatif dengan pendekatan deskriptif. teknik sampling yang digunakan untuk menetapkan sampel ialah teknik purposive sampling. Instrument yang digunakan model skala likert. Subjek penelitian adalah mahasiswa BK IAIN Batusangkar tahun akademik 2019/2020. Hasil penelitian menunjukkan bahwa kompetensi mahasiswa dalam pelaksanaan layanan BKp yang terendah ialah pada tahap peralihan yaitu $63 \%$ sedangkan pada tahap kegiatan sangat tinggi yaitu $83 \%$. Pada tahap penyimpulan yaitu sebanyak $73 \%$ dikategorikan rendah. Dan pada tahap pengakhiran yaitu sebanyak $77 \%$ dikategorikan sedang. Temuan penelitian memberikan dampak menghasilkan calon konselor handal dimasa depan dengan memiliki kompetensi pelayanan bimbingan kelompok.
\end{abstract}

Kata Kunci: Bimbingan dan Konseling, Layanan Bimbingan Kelompok

JIES is licensed under a Creative Commons Atribution-Share Alike 4.0 Internasional Licence 


\section{PENDAHULUAN}

Pendidikan merupakan suatu upaya sadar dan sistematik dalam membantu, membimbing pertumbuhan dan perkembangan anak untuk mencapai kedewasaan secara keseluruhan (Amalina, 2020; Warmansyah, 2020). Pendidikan tidak hanya mempersoalkan aspek intelektual belaka, tetapi jauh dari itu, pendidikan mencakup pula aspek kesadaran untuk berhubungan dengan kemanusiaan anak didik dalam totalitasnya (Mualim \& Saputra, 2021; Perdawati \& Hafulyon, 2021; Turrahmi \& Amra, 2021). Proses pendidikan di sekolah yang saling mendukung bidang pembinaan peserta didik yang diwujudkan dalam bentuk pemberian layanan bimbingan dan upaya lainnya kepada peserta didik dengan memperhatikan kemungkinan-kemungkinan dan kenyataan adanya masalah baik yang muncul dalam penyelenggaraan dua bidang kegiatan pendidikan di atas maupun masalah lain di luar bidang tersebut (Maharani et al., 2018; Pohan \& Indra, 2020; Sabri et al., 2020).

Peran dari layanan bimbingan untuk upaya dalam suatu masalah dari peserta didik dalam keseluruhan pendidikan di sekolah (Sartika \& Yandri, 2019). Salah satu layanan bimbingan kelompok. Menurut Mirawati, (2018) mengatakan bahwa, bimbingan kelompok merupakan layanan bimbingan yang diberikan dalam suasana kelompok untuk membantu mereka menyusun rencana dan keputusan yang tepat serta memberikan informasi yang bersifat pribadi. Layanan Bimbingan Kelompok (BKp) berperan dua pihak yaitu pemimpin kelompok dan anggota kelompok. Pemimpin kelompok pada layanan BKp ini adalah konselor yang terlatih dan berwenang menyelenggarakan praktik konseling profesional. Melaksanakan tugas dan kewajiban profesional dalam layanan Bimbingan Kelompok (BKp), pemimpin kelompok mampu membentuk kelompok yang mengarahkan sehingga terjadi dinamika kelompok (Ulandari \& Juliawati, 2019).

Kompetensi guru BK dalam layanan BKp dapat dilihat dari beberapa tahapan yaitu: tahap pembentukan, tahap peralihan, tahap kegiatan, tahap penyimpulan, tahap pengakhiran (Widodo et al., 2021). Kemampuan mahasiswa dalam kompetensi profesional merupakan kemampuan dan keterampilan yang harus dimiliki oleh guru Bimbingan dan Konseling (BK), khususnya pada mahasiswa BK dalam pelaksanaan layanan Bimbingan Kelompok (BKp). Di mana layanan Bimbingan Kelompok (BKp) tersebut memerlukan pemimpin kelompok sebagai profesional dalam pelaksanaan layanan BKp (Pohan \& Indra, 2020).

Konselor memiliki 4 kompetensi yaitu kompetensi pedagogik, kompetensi kepribadian, kompetensi social dan kompetensi professional (Kurniawan, 2015). Kemampuan mahasiswa dalam kompetensi profesional terlihat dari kemampuan dan keterampilan yang harus dimiliki oleh guru Bimbingan dan Konseling (BK), khususnya pada mahasiswa BK dalam pelaksanaan layanan Bimbingan Kelompok (Bkp). Di mana layanan Bimbingan Kelompok (BKp) tersebut memerlukan pemimpin kelompok sebagai profesional dalam pelaksanaan layanan BKp tersebut. Dapat dilihat dari mahasiswa BK yang kurang optimal untuk pelaksanaan layanan Bimbingan Kelompok (BKp) dengan profesional. Hal tersebut dapat sejalan dengan penelitian Sartika \& Yandri, (2019), 
menyebutkan bahwa kompetensi mahasiswa BK sebagai calon guru BK dalam layanan Bimbingan Kelompok (BKp) sangat berpengaruh bagi kelancaran layanan tersebut.

Keterkaitan antara kompetensi dalam pelaksanaan layanan BKp sangat penting dan beberapa dari guru BK belum terlaksana. Hal tersebut terlihat dari pelayanan kelompok yang belum berjalan dengan semestinya. kompetensi dalam melaksanakan layanan bimbingan kelompok sangat berpengaruh untuk menganalisis kebutuhan konseli, dalam menyusun program bimbingan dan konseling yang berkelanjutan berdasar kebutuhan konseli secara komprehensif dengan pendekatan perkembangan dalam suatu kelompok itu.

Mahasiswa sebagai calon guru BK memberikan layanan BKp kepada siswa di sekolah. Kompetensi mahasiswa sebagai calon guru BK dalam pelaksanaan layanan BKp untuk penguasaan dan implementasi kompetensi profesional tersebut mampu menyelenggarakan layanan bimbingan kelompok yang mutu dan bermartabat. Salah satunya dalam melaksanakan, layanan BKp perlu adanya pemimpin anggota kelompok yang profesional. Kompetensi mahasiswa BK dalam pelaksanaan layanan BKp ini tidak dapat di pisahkan. Guru BK harus menguasai ke empat kompetensi tersebut. Namun berdasarkan wawancara dengan mahasiswa BK terkait dengan pelaksanaan layanan bimbingan kelompok belum terlaksana secara optimal. Kompetensi mahasiswa BK dalam pelaksanaan layanan BKp.

Selama ini guru BK belum mengaplikasikan pendekatan klien dalam layanan. Selain itu seharusnya pelayanan kelompok terjadi atas memanfaatkan dinamika kelompok. Dengan kata lain, belum mendapatkan penyelesaian dengan adanya kelompok. Selama ini dari guru BK telah memprogramkan pelaksanaan layanan BKp dilakukan minimal satu minggu sekali, akan tetapi yang selama ini terjadi program tersebut baru sekedar wacana, belum ada realisasinya. Hal tersebut disayangkan karena pelayanan kelompok yang belum berjalan dengan semestinya.

Hasil penelitian yang dilakukan oleh Amri et al., (2016), menyebutkan bahwa layanan BKp memungkinkan peserta didik konseli (secara bersama-sama melalui dinamika kelompok memperoleh berbagai bahan dari narasumber tertentu (terutama dari guru pembimbing/konselor) dan atau membahas secara bersama-sama pokok bahasan (topik) tertentu. Lebih lanjut hasil penelitian yang dilakukan oleh (Ulandari \& Juliawati, 2019), menemukan bahwa strategi lain dalam layanan bimbingan dan konseling dapat diberikan melalui bimbingan kelompok. Bimbingan kelompok dimaksudkan untuk mencegah berkembangnya masalah setelah kesulitan pada diri konseli (siswa). Tujuan dan fungsi bimbingan kelompok untuk membahas topik-topik umum yang menjadi kepedulian bersama anggota kelompok, dan dengan memanfaatkan dinamika kelompok topik tersebut dibahas secara bersama-sama, dimana setiap anggota kelompok diharapkan aktif dalam mengeluarkan pendapat, ide, gagasan serta tanggapannya terhadap topik tersebut (Pranata \& Barus, 2019). 
Masalah-masalah yang telah diuraikan tersebut sangat menarik dan pentingnya penelitian ini di kaji untuk mengetahui bagaimana kompetensi mahasiswa BK sebagai calon konselor dalam pelaksanaan layanan bimbingan kelompok (BKp).

\section{METODE PENELITIAN}

Jenis penelitan yang digunakan adalah penelitian deskriptif kuantitatif. Metode penelitian deskriptif kuantitatif digunakan untuk memetakan dan mengidentifikasi bagaimana kompetensi mahasiswa dalam pelaksanaan layanan BKp. Data tentang kompetensi profesional mahasiswa sebagai calon guru BK/konselor dalam pelaksanaan layanan BKp dengan 30 responden yang diperoleh dengan cara memberikan skala likert kepada mahasiswa BK semester VI secara online dengan membagikan angket berbentuk link.

Jenis pengumpulan data yang digunakan adalah instrument skala likert. Penyebaran instrument skala likert dilakukan secara on line melalui aplikasi whatsapp dan link. Pada analisis, peneliti melakukan telaah validasi dan reliabilitas. Berdasarkan hasil uji validitas pernyataan, seluruh pernyataan berjumlah 31 pernyataan sebelum melakukan uji validitas dan setelah melakukan uji validitas berjumlah 28 pernyataan dengan taraf signifikan 5\%. Berdasarkan uji reliabilitas dengan menggunaka alpha cronbach, instrument ini memiliki realibilitas yaitu 0,735. Analisis data dengan teknik analisis deskriptif kuantitatif.

\section{HASIL DAN PEMBAHASAN}

Temuan penelitian secara umum tentang kompetensi profesional 30 orang responden mahasiswa sebagai calon guru bk/konselor dalam pelaksanaan layanan BKp di kategorikan tinggi. Secara keseluruhan analisis angket didapatkan data bahwa kompetensi mahasiswa bk IAIN Batusangkar berada pada kategori yaitu sebanyak 2 orang responden dengan persentase $6 \%$. Selanjutnya 26 orang responden memiliki kategori kompetensi profesional dalam pelaksananaan layanan BKp dengan persentase $87 \%$, kemudian untuk kategori kompetensi dalam pelaksananaan layanan BKp didapatkan 2 orang responden dengan persentase $7 \%$

Hasil penelitian ini dideskripsikan berdasarkan hasil tanggapan responden kemudian hasil tersebut digambarkan sesuai dengan kategori skor skala likert. Kompetensi mahasiswa sebagai calon guru Bimbingan Dan Konseling (BK) dalam pelaksanaan layanan Bimbingan Kelompok (BKp) diukur berdasarkan 5 indikator.

Dari ke 5 tahap atau indikator pelaksanaan layanan Bkp pada mahasiswa BK IAIN Batusangkar sebagai berikut: Pada Indikator tahap pembentukan ini terdiri dari 7 item. Bedasarkan 7 item tersebut terlihat bagaimana kompetensi mahasiswa BK dalam pelaksanaan layanan BKp, diperoleh data bahwa pada umumnya kompetensi mahasiswa BK dalam pelaksanaan layanan BKp berada pada kategori tinggi, hal ini terlihat dari keseluruhan tahap pembentukan dengan jumlah total 149 dikategorikan tinggi. 
Indikator tahap peralihan, ini terdiri dari 4 item pernyataan. Bedasarkan 4 item tersebut akan terlihat bagaimana kompetensi mahasiswa BK dalam pelaksanaan layanan $\mathrm{BKp}$, diperoleh data bahwa pada umunya kompetensi mahasiswa dalam pelaksanaan layanan BKp berada pada kategori sangat rendah, hal ini terlihat dari keseluruhan tahap peralihan dengan jumlah total 31 dikategorikan sangat rendah. Sitompul, (2015), menyebutkan bahwa tahap peralihan pada hakikatnya merupakan jembatan antara tahapan pembentukan dengan tahap selanjutnya, yaitu tahap kegiatan. Tahap peralihan ini merupakan tahap penegasan bahwa seluruh anggota telah memahami maksud, tujuan dan prosedur penyelenggaraan bimbingan atau klien kelompok. Pada tahap ini pemimpin kelompok menjelaskan apa yang akan dilakukan oleh masing-masing kelompok.

Indikator tahap kegiatan, 6 item pernyataan. Berdasarkan 6 item tersebut akan terlihat bagaimana kompetensi mahasiswa BK dalam pelaksanaan layanan BKp, diperoleh data bahwa pada umumnya kompetensi mahasiswa BK dalam pelaksanaan layanan BKp berada pada kategori tinggi, hal ini terlihat dari keseluruhan tahap kegiatan dengan jumlah total 180 dikategorikan sangat tinggi.

Indikator Tahap Penyimpulan, 4 item pernyataan, berdasarkan 4 item tersebut akan terlihat bagaimana kompetensi mahasiswa BK dalam pelaksanaan layanan BKp, diperoleh data bahwa pada umumnya kompetensi mahasiswa BK dalam pelaksanaan layanan BKp berada pada kategori rendah, hal ini terlihat dari keseluruhan tahap penyimpulan dengan jumlah total 87 dikategorikan rendah.

Indikator Tahap Pengakhiran, 10 item pernyataan, berdasarkan 10 item tersebut akan terlihat bagaimana kompetensi mahasiswa BK dalam pelaksanaan layanan BKp, diperoleh data bahwa pada umumnya kompetensi mahasiswa BK dalam pelaksanaan layanan BKp berada pada kategori sedang, hal ini terlihat dari keseluruhan tahap penyimpulan dengan jumlah total 118 dikategorikan sedang.

Hasil penelitian sejalan dengan temuan Alamri, (2015), mengatakan bahwa “ layanan kelompok terjadi atas dasar sukarela dan memanfaatkan dinamika kelompok, dengan kata lain belum mendapatkan penyelesaian dengan adanya kelompok. Untuk layanan dalam format kelompok seperti layanan bimbingan kelompok yang idealnya volume pelaksanaan 12\%-20\% juga belum terlaksana. Hasil penelitian yang dilakukan oleh menemukan bahwa

\section{KESIMPULAN}

Penelitian ini menjawab kaitan tentang kompetensi konselor yang dimiliki oleh calon guru bimbingan konseling berkaitan dengan pelaksanaan layanan Bimbingan kelompok (BKp). Indikator pelaksanaan layanan Bkp pada mahasiswa Bimbingan Konseling (BK), yaitu tahap pembentukan, peralihan, kegiatan, penyimpulan dan pengakhiran. Kompetensi tersebut sejalan dengan pengalaman yang diperoleh mahasiswa. Layanan bimbingan kelompok yang belum dapat terlaksana secara baik dan optimal, maka dapat menjadi salah satu penghambat pelaksanaan layanan BKp. Apabila 
layanan kelompok belum terlaksana maka hubungan antara mahasiswa dengan peserta didik akan berpengaruh dalam proses layanan BKp tersebut.

\section{DAFTAR PUSTAKA}

Alamri, N. (2015). Layanan Bimbingan Kelompok Dengan Teknik Management Untuk Mengurangi Perilaku Terlambat Masuk Sekolah. Konseling GUSJIGANG, 1(1), 11.

Amalina, A. (2020). Pembelajaran Matematika Anak Usia Dini di Masa Pandemi COVID-19 Tahun 2020. Jurnal Obsesi : Jurnal Pendidikan Anak Usia Dini, 5(1), 538. https://doi.org/10.31004/obsesi.v5i1.592

Amri, K., Syahniar, S., \& Nirwana, H. (2016). Peningkatan Kemampuan Mengemukakan Pendapat Melalui Layanan Bimbingan Kelompok. Konselor, 3(2), 75. https://doi.org/10.24036/02014323239-0-00

Kurniawan, L. (2015). Pengembangan Program Layanan Bimbingan Dan Konseling Komprehensif di SMA. Jurnal Psikologi Pendidikan Dan Konseling: Jurnal Kajian Psikologi Pendidikan Dan Bimbingan Konseling, 1(1), 1. https://doi.org/10.26858/jpkk.v1i1.1351

Maharani, L., Masya, H., \& Janah, M. (2018). Peningkatan Keterampilan Sosial Peserta Didik SMA Menggunakan Layanan Bimbingan Kelompok Dengan Teknik Diskusi. KONSELI: Jurnal Bimbingan Dan Konseling, 5(1). https://doi.org/https://doi.org/10.24042/kons.v5i1.2658

Mirawati, M. (2018). Penggunaan Layanan Bimbingan Kelompok Dan Kekompakan Kelompok Dalam Memantapkan Perencanaan Karir Siswa Sma Budi Agung Medan. Kogniti, 3(1). https://doi.org/http://dx.doi.org/10.22303/kognisi.3.1.2018.11-22

Mualim, R., \& Saputra, M. F. (2021). Optimizing Online Learning during Covid 19 Pandemic in Junior High School. Journal of Islamic Education Students (JIES), 1(1), 19. https://doi.org/10.31958/jies.v1i1.3193

Perdawati, R. E., \& Hafulyon, H. (2021). The Effect of Administrative Services on Students' Satisfaction. Journal of Islamic Education Students (JIES), 1(1), 39. https://doi.org/10.31958/jies.v1i1.3024

Pohan, R. A., \& Indra, S. (2020). Efektivitas Layanan Bimbingan Kelompok dalam Meningkatkan Kegiatan Merespon Pembelajaran. Islamic Counseling: Jurnal Bimbingan Konseling Islam, 4(1), 17. https://doi.org/10.29240/jbk.v4i1.1280

Pranata, Y. Y., \& Barus, G. (2019). Peningkatan Karakter Bersahabat Melalui Layanan Bimbingan Kelasikal dengan Pendekatan Experiential Learning. Solution, Journal of Counseling and Personal Development, 1(1), 1-14.

Sabri, A., Warmansyah, J., Amalina, A., \& Aswirna, P. (2020). Implementasi Pengintegrasian Keislaman Dalam Pengenalan Konsep Matematika Anak Usia Dini. 2020, 4(1), 23-30. https://doi.org/doi.org/10.15548/mej.v4i1.1240 
Sartika, M., \& Yandri, H. (2019). Pengaruh Layanan Bimbingan Kelompok Terhadap Konformitas Teman Sebaya. Indonesian Journal of Counseling and Development, 1(1), 9-17. https://doi.org/10.32939/ijcd.v1i1.351

Sitompul, D. N. (2015). Pengaruh Penerapan Layanan Bimbingan Kelompok Teknik Role-Playing Terhadap Perilaku Solidaritas Siswa dalam Menolong Teman. EduTech: Jurnal Ilmu Pendidikan Dan Ilmu Sosial, 1(1). https://doi.org/http://dx.doi.org/10.30596\%2Fedutech.v1i01.265

Turrahmi, M., \& Amra, A. (2021). Implementing Student Management for Children with Special Needs in Special Schools. Journal of Islamic Education Students (JIES), 1(1), 1. https://doi.org/10.31958/jies.v1i1.3017

Ulandari, Y., \& Juliawati, D. (2019). Pemanfaatan Layanan Bimbingan Kelompok Untuk Meningkatkan Kecerdasan Emosi Siswa. Indonesian Journal of Counseling and Development, 1(1), 1-8. https://doi.org/10.32939/ijcd.v1i1.350

Warmansyah, J. (2020). Supervisi Akademik Kepala Sekolah Taman Kanak-kanak Dimasa Pandemi Covid 19. Tadbir : Jurnal Studi Manajemen Pendidikan, 4(2), 175. https://doi.org/10.29240/jsmp.v4i2.1695

Widodo, H., Sari, D. P., Wanhar, F. A., \& Julianto, J. (2021). Pengaruh Pemberian Layanan Bimbingan dan Konseling Terhadap Komunikasi Interpersonal Siswa SMK. Edukatif: Jurnal Ilmu Pendidikan, 3(4), 2168-2175. https://doi.org/10.31004/edukatif.v3i3.1028 